\title{
Public-private partnership as a financial mechanism for the development of professional education
}

\author{
Larisa Desfonteines ${ }^{1,{ }^{*}}$, Elena Korchagina ${ }^{1}$, and Victoria Senchugova $^{1}$ \\ ${ }^{1}$ Graduate School of Service and Trade, Institute of Industrial Management, Economics and Trade of \\ Peter the Great St. Petersburg Polytechnic University, Polytechnicheskaya, 29, 195251, St. \\ Petersburg, Russia.
}

\begin{abstract}
.
Research background: The processes of globalization in the world economy lead to international competition of professional education. Providing the labor market with qualified specialists is based on a flexible system of financing additional education. The article analyzes of publicprivate partnership in the field of additional professional education. Special attention is paid to the interaction of business, universities, the state and public organizations in the framework of public-private partnership in the implementation of programs of additional professional education.

Purpose of the article: The main goal of the study is to consider options for public-private partnership in the system of additional professional education based on pooling resources and distribution of income and risks between the state and private sector.

Methods: The research uses methods of analysis of statistical data of various forms of public-private partnership in the education system, the method of comparative analysis of corporate reports of additional professional education.

Findings \& Value added: The forms of public-private partnership should be used differentially in accordance with the effectiveness of projects. The processes of globalization require expanding the forms of professional adult education based on interaction with labor market actors, legislative authorities, representatives of regional business, and public organizations, which will not only provide funding for adult education, but also meet the requirements of the innovative economy.
\end{abstract}

Keywords: public-private partnership; additional professional education; human capital; education financing; educational program.

JEL Classification: $A 11 ; A 12 ; A 13$

*Corresponding author: 1ja2@yandex.ru 


\section{Introduction}

The globalization process has affected not only the production and financial structures of countries, but also changed the requirements for labor resources and, as a result, for the education system. International competition in the field of education, rapid development of information technologies are combined with an increase in the life expectancy of the population. Demographic changes related to the aging of the population affected all countries in the Euro area. Increasing the retirement age and internationalization of the economy place ever-increasing demands on the quality of professional education. For example, food quality requirements change in accordance with the introduction of new technologies, which changes the requirements for training specialists in this field [1]. In the next 10 years, about $80 \%$ of the technologies used today will be outdated, while four-fifths of employees will have an education received more than 10 years ago. The requirement of continuous updating of knowledge, skills and abilities becomes a necessity that defines a new paradigm of education - continuous improvement of knowledge, skills and abilities throughout the entire period of labor activity of the population. Technologies of training and interaction with the audience are changing [2] and technologies in management and management theory [3].

Additional professional education is a key element of the system of continuing education, which ensures effective and timely satisfaction of the educational system's needs and requests arising in the modern labor market, by preserving and developing the human resources potential of the innovative economy in the context of globalization. The modern labor market is changing managers ' strategic approaches to analyzing business processes and competition. The new economic reality also changes the logical algorithms of managers themselves, forcing them to constantly improve their skills and master new knowledge and skills $[4,5]$.

The use of public-private partnership as a promising direction of interaction between the state, educational institutions, public and private structures is of fundamental importance in the formation of new tasks and functions of DPO in the system of continuing education.

\section{Methods}

The research uses methods of analysis of statistical data of various forms of publicprivate partnership in the education system, the method of comparative analysis of corporate reports of additional professional education. The article uses statistical data of the VSP group. Analytical report on the functioning of the system of additional professional education in the Russian Federation. Scientific literature sources are analyzed in the article.

The statistical forecast is based on a comparative analysis of data on the development of public-private partnerships in the Russian Federation. Conclusions are made based on the analysis of legislative acts of the Russian Federation and regional laws. The article analyzes statistical data from official sources of state statistics of the Russian Federation.

\section{Results and Discussion}

Analysis of statistical data on the use of public-private partnerships in the Russian Federation [6] allows us to conclude that concession agreements are most common:

- $71 \%$ of the subjects of the Russian Federation used concession agreements,

- $40 \%$ of subjects used public-private partnership agreements within the framework of regional legislation, 
- $36 \%$ of the subjects used lease agreements of state or municipal property with investment obligations of the lessee. The results are shown in figure 1.

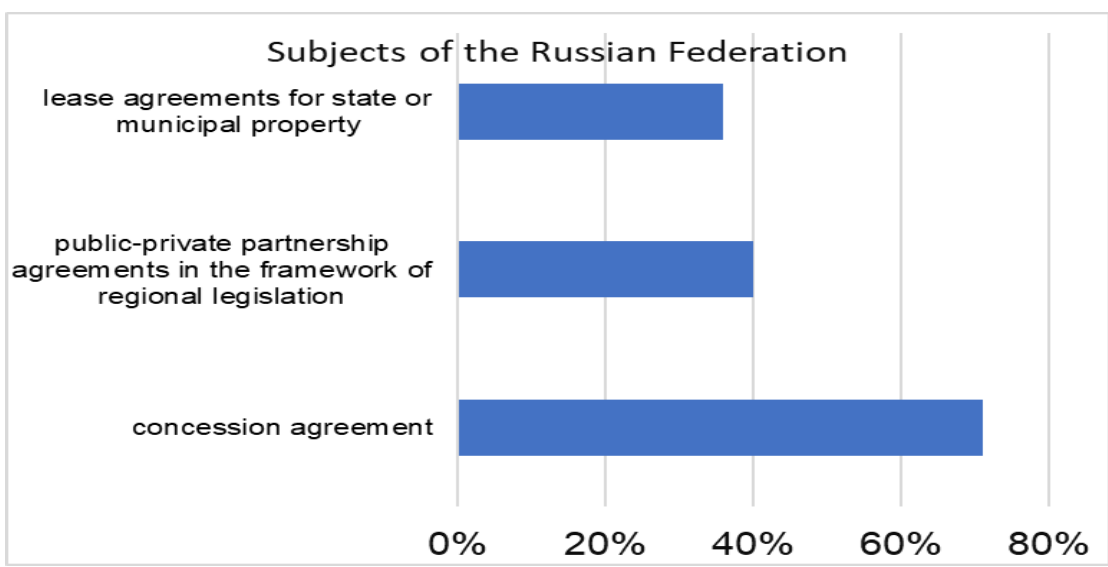

Fig. 1. Types of public-private partnership in the Russian Federation [6].

According to The center for public-private partnership development, there is an increase in projects using public-private partnerships in the Russian Federation. The results of data analysis for the number of projects are shown in figure 2 .

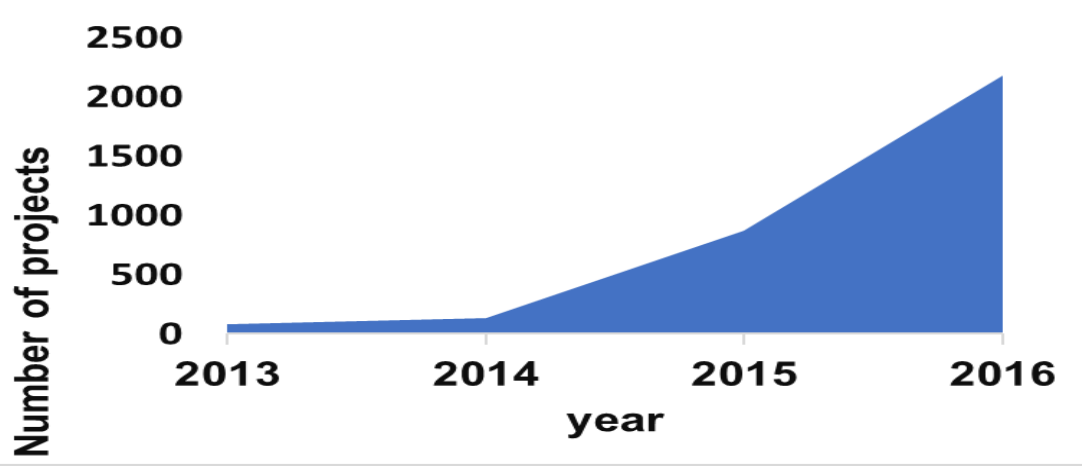

Fig. 2. Number of public-private partnership projects in the Russian Federation [6].

National and international educational systems use three main forms of cooperation between the private sector and educational organizations;

- charity,

- social partnership,

- public-private partnership.

Public-private partnership in the field of education is an Alliance between the state and business aimed at implementing educational projects based on legislative acts and special agreements. The effectiveness of public-private partnership is ensured not so much by the direct addition of financial resources on the terms of co-financing, but by the fullest use of the unique capabilities of each of the project participants. Public-private partnership provides unique opportunities for the development of the system of additional education, taking into account cultural and historical traditions [7, 8].

In Europe, the United States, and Canada, the interaction of educational organizations of additional education and business within the framework of public-private partnership began 
most actively in the 80 -ies of the last century. Every year, more than $\$ 7.8$ billion is attracted to the world economy through public-private partnership in the system of additional education. The share of the economically active population of developed European countries included in the process of continuing professional education reaches $90 \%$. So, in Austria it is $89.2 \%$, in Denmark $-79.7 \%$, Finland $-77.3 \%$, Sweden $-71 \%$, Switzerland $-68 \%$, France $-51 \%$, Germany $-41.9 \%$, great Britain $-37.6 \%$. In Russia, this indicator does not exceed 22.4\% [9]. For example, in 2012, according to The Boston Consulting Group BCG, companies from The G20 countries invested almost \$ 400 billion in improving the skills of their employees. A number of developed countries, such as the USA, Germany and France, have become leaders of such investments. Capital markets are responding positively to these investments.

The results of a global survey of 4,300 top HR managers from more than 100 countries conducted by BCG in 2012 showed that over the past ten years, companies focused on human capital development have provided higher shareholder returns and exceeded the industry average by eight times [9]. In the Russian Federation, the total number of students enrolled in various programs of additional professional education was just under 2 million people [10], approximately $2 \%$ of the economically active population of the country. In addition, professional technical education programs in the United States at community colleges are increasingly seen as an attractive alternative to four-year colleges [11]. Additional professional education can reduce the negative consequences of gender differences in the choice of professional activities [12]. Analysis of the gender structure of the modern labor market proves the trend of increasing women's labor in the future [13], which will inevitably lead to the acquisition of new knowledge and professional skills by both women and men. Due to changes in the structure of the labor market, the human capital of large corporations will also change [14]. At the same time, the processes of globalization contribute to the creation of multinational corporations. In an empirical analysis of the merger of the banking sector by Finnish Merita and Swedish Nordbanken, it is proved that language skills become reinforcing or weakening resources in the organizational communication of multinational corporations [15]. Consequently, publicprivate partnership projects in additional professional education can significantly help employees of multinational corporations learn new skills in organizational communication standards. Research in the field of management confirms the need for continuous improvement of new forms of management [16], which indirectly indicates the possibility of using public-private partnership in additional professional education.

The main risk of participation in public-private partnership projects for investors is the probability of non-return on investment, which is associated with an insufficient level of profitability of projects, as well as the high cost of credit resources. For businesses, risks are also associated with a low level of coordination, inefficient public administration, complex and lengthy licensing procedures, and the potential unreliability of state institutions in terms of compliance with agreements.

For a public partner, the risks of participating in projects are related to the potential unreliability of the private partner, the insufficient level of its competence, and the low interest of the business in long-term investments. Social risks are also relevant for the state.

Among the most frequently used forms of public-private partnership in the system of additional education are:

1. Contracts are a type of administrative contract concluded between the state (local government body) and a private firm for the implementation of certain socially necessary and useful activities in the system of additional education. An example of this practice is contracts for the performance of works, for the provision of public services, for management, for the supply of products or equipment for the needs of organizations of additional education, for the provision of technical assistance. At the same time, in 
administrative contractual relations, property rights are not transferred to a private partner, and the costs and risks are fully borne by the state.

The interest of a private partner is that under the contract it gets the right to a specified share in the income, profit or collected payments. This form is widely used in Europe and North America, as well as in Asia and Latin America.

2. Lease agreements. The peculiarity of lease relations between organizations of additional education and private business is that under the conditions specified in the contract, state or municipal property is transferred to a private partner for temporary use and for a certain fee. In the case of a lease agreement, the lessee always has the right to buy out state or municipal property. This form is interesting because the property purchased for rent, leasing, will cost less than when buying or purchasing on credit. Leasing payments are usually lower than Bank interest, but most importantly, leasing allows you to seriously save on taxes. Lease payments are fully charged to cost and, accordingly, reduce the taxable base for income tax, while the loan is repaid from profit. This form is widely used in all developed countries.

3. Concession (concession agreement) is a specific form of relationship between an organization of additional education and a private partner in recent years, this form of public-private partnership is becoming more widespread in Russia. Its peculiarity lies in the fact that the organization of additional education within the framework of partnership relations, while remaining the full owner of the property that is the subject of the concession agreement, authorizes the private partner to perform the functions stipulated in the agreement for a certain period of time and grants it for this purpose the appropriate powers necessary to ensure the normal functioning of the concession object. For the use of state or municipal property, the concessionaire pays a fee on the terms stipulated in the concession agreement. The state benefits from such partnerships, as they gain access to corporate experience in management, strategic planning, solving current problems, experience in the labor market, professional skills development, effective service delivery, and logistics support.

4. Stock option - equity participation of private capital in state organizations of additional education (joint ventures). Joint-stock companies with state participation are created that give the right to manage (not lower than the blocking package; investment projects that are partially financed by budget investments, loans, grants with subsequent transfer of the investment object to private ownership or with private capital participating in the management of the state object).

5. Special economic region and projects in the field of additional education, in which private investors are granted tax and customs benefits, benefits for the use of land, infrastructure, etc.

Forms and mechanisms of public-private partnership can be grouped in two directions: involvement in the educational process or evaluation of its results.

The first direction is joint work with the business community to develop, improve and implement programs.

The second area of joint activity of state bodies, educational institutions of additional professional education, the business community and employers ' associations, social organizations to establish an independent education quality assessment: from identifying qualification requirements, professional standards, the formation of professionally-public accreditation of education courses, resource support to the educational process, and then to the evaluation of the results obtained through the assessment center and certification of qualifications.

Public-private partnership projects facilitate access to global capital markets. For example, investors in the Moscow school of management's Skolkovo project, implemented as part of a public-private partnership, are not only representatives of domestic businesses, 
but also foreign companies. So, representatives of business structures plan to allocate $\$ 5$ million each over three years for the construction of the campus, promotion of new educational programs, organization of internships in their companies and methodological assistance.

Alumni associations as a mechanism of public-private partnership is one of the most promising areas of interaction between the state, educational institutions, public and private structures. However, this mechanism has not yet been properly implemented in our country, but it has a great potential. Graduates of such organizations help establish business and professional contacts, initiate joint projects, organize interaction with the administration and students of the educational institution, conduct joint events, promote employment and help each other in finding a job. Members of alumni associations actively participate in improving the content of the educational process.

For example, the Association's mission: "Creating a community that promotes the personal and professional potential of each participant."

Main goals of the Association:

- establishing mutually beneficial, effective management relations between society, business and state authorities, as well as at the international level;

- creating an educational and business environment that promotes the emergence, testing and effective implementation of projects of the Association's members aimed at modernization and innovative development;

- $\quad$ increasing the prestige of studying.

The main goal of the career planning Center is to assist in the employment of graduates, help in planning a professional career.

Main tasks of the Center:

- conducting monitoring studies of the regional labor market;

- creating a system for informing students about the state of the labor market;

- formation of practical skills and abilities of job search, employment and career building;

- consultations with lawyers and psychologists on employment issues, meetings with employers and labor market specialists.

The mechanism for financing additional professional education using public-private partnership is designed to solve the following tasks:

- development and creation of innovative projects, including implementation of innovative scientific projects,

- consulting, methodological, information services and training in innovation activities,

- development, implementation and use of educational innovations, solving applied problems for commercial organizations and government agencies.

\section{Conclusion}

Public-private partnership projects are becoming more and more popular because serious changes in the asset structure of national economies in the direction of increasing the share of intangible assets significantly increase the importance of studying and using the experience of managing intangible assets in education. The quality of any production process is determined by the consumer properties of the product obtained at the output. The educational process is no exception. Globalization processes cover all aspects of modern society, from socio-political [17] to the development of tourist destinations [18] and improvement of marketing strategies in retail $[19,20]$. The lack of professionalism of specialists can be compensated by the system of additional professional education [21]. It is proposed to use public-private partnership as a financial mechanism for additional 
professional education. An important area of development of public-private partnership mechanisms is the implementation of joint research projects, the creation of joint research laboratories and the formation of innovative infrastructure facilities.

A promising area of public-private partnership is grants and grant programs in the form of gratuitous financing of specific areas of activity: programs, activities and research, scientific activities, projects of additional professional education.

Another direction is the creation and development of public participation institutions as a mechanism for implementing public-private partnership in the field of education. These institutions include Supervisory, Trustee, public, management and other types of councils established in educational institutions. These institutions allow you to connect to the development of the education system, material, intellectual and academic base of the institution as representatives of the educational institutions, and representatives of the state, private business, academia, the General public, students.

Building an effective model of economic and organizational forms of interaction between institutions of additional professional education with labor market entities, legislative authorities, representatives of regional business, public organizations, aimed at implementing promising mechanisms of public-private partnership will not only ensure the flow of additional funds to additional education, but also becomes a guarantee of its flexibility and adequacy to the requirements of an innovative economy.

\section{References}

1. Asfondiarova I., Demchenko V., Katkova N., Ivanova M., Belokurova E. (2019). The possibility of using lactic additives and sonochemical technology in the production of preserves. Proceedings of E3S Web of Conferences, Topical Problems of Green Architecture, Civil and Environmental Engineering (TPACEE 2019).

2. Giorgi, S. (2017).The Mind and Heart of Resonance: The Role of Cognition and Emotions in Frame Effectiveness. Journal of Management Studies, 54(5), 711-738.

3. Alvesson, M., Hardy, C., Harley, B. (2008). Reflecting on reflexivity: Reflexive Textual Practices in Organization and Management Theory. Journal of Management Studies, 45(3), 480-501.

4. Wright, R., Paroutis, S., Blettner, D. (2013). How Useful Are the Strategic Tools We Teach in Business Schools? Journal of Management Studies, 50(1), 92-125.

5. Cornelissen, J., Floyd, S. W. (2009). The future ahead: imagination, rigour and the advancement of management studies. Journal of Management Studies, 46, 11-5.

6. Public-private partnership in Russia 2016-2017: current state and trends, rating of regions. (2016). Moscow: Association Center for PPP development.

7. Beamish, P. (2020). The Transferability of Western Business Education to the East. Journal of Management Studies, 57(1), 163-170

8. Smith, A., Kaminishi, M. (2020). Confucian Entrepreneurship: Towards a Genealogy of a Conceptual Tool. Journal of Management Studies, 57(1), 25-56.

9. BCG Review № 28. (December, 2013). Retrieved from : https://imagesrc.bcg.com/Images/BCG\%20Review\%20December\%202013_tcm27-158423.pdf

10. Analytical report on the functioning of the system of additional professional education in the Russian Federation in 2013. (2014). Moscow: Federal state Research Institute of ITT Informika. 
11. Stevens, A., Kurlaender, M., Grosz, M. (2019). Career Technical Education and Labor Market Outcomes: Evidence from California Community Colleges. Journal of Human Resources, 54(4), 986-1036.

12. Landaud, F., Ly, S.T., Maurin, E. (2020). Competitive Schools and the Gender Gap in the Choice of Field of Study. Journal of Human Resources, 55(1), 278-308.

13. Desfonteines, L., Korchagina, E. (2019). Study of Gender Structure of the Russian Labor Market. Proceedings of the 33d International Business Information Management Association Conference, IBIMA 2019: Education Excellence and Innovation Management through Vision 2020 (pp. 2216-2221). Norristown: International Business Information Management Association.

14. Robinson, C. (2018). Occupational Mobility, Occupation Distance, and Specific Human Capital. Journal of Human Resources, 53(2), 513-551.

15. Vaara, E., Tienari, J., Piekkari, R., Säntti, R. (2005). Language and the circuits of power in a merging multinational corporation. Journal of Management Studies, 42, $595-623$.

16. Sergeev, S., Kirillova, T., Krasyuk, I. (2019) Modelling of Sustainable Development of Megacities under Limited Resources. Proceedings of the E3S Web of Conferences.

17. Desfonteines, L., Semenova, Yu. (2019). The Role of Social Networks in the Political Life of Society. Proceedings of the 33d International Business Information Management Association Conference, IBIMA 2019: Education Excellence and Innovation Management through Vision 2020 (pp. 4582-4585). Norristown: International Business Information Management Association.

18. Lukina, O., Kurochkina, A., Karmanova, A. (2020). Assessment of tourism development in Arctic entities. Proceedings of E3S Web of Conferences.

19. Krasyuk, I., Yanenko, M., Nazarova, E. Conceptual and strategic framework for the digitalization of modern retail as part of innovative marketing. (2020). Proceedings of E3S Web of Conferences.

20. Korchagina, E., Desfonteines, L. (2019). Internal resources of increasing retail efficiency. Intellectual Economics, 13(2), 122-130.

21. Korchagina, E., Desfonteines, L., Strekalova, N. (2020). Problems of training specialists for trade in the conditions of digitalization. Proceedings of E3S Web of Conferences. 